Ann. Biol. anim. Bioch. Biophys., 1977, 17 (3 B), 459-473.

\title{
Light control of prolactin secretion in sheep. Evidence for a photoinducible phase during a diurnal rhythm
}

\author{
par J.-P. RAVAULT *, R. ORTAVANT
}

\author{
Station de Physiologie de la Reproduction, I.N.R.A. \\ Nouzilly 37380 Monnaie, France \\ * Laboratoire de Physiologie Comparée, Faculté des Sciences, \\ Parc Grandmont, 37200 Tours, France
}

Summary. The secretion of prolactin comes under important seasonal variations in sheep. Thus, in the ram the highest levels are in summer and the lowest in winter. These variations of secretion are under light control because illumination of long duration (long photoperiods) produces high prolactin levels $(220 \pm 2 \mathrm{ng})$; short photoperiods produce low levels $(12 \pm 2 \mathrm{ng})$.

Using the hypothesis of Bunning, we study a photoinducible phase during diurnal rhythm. For this purpose, rams preconditioned either in short photoperiods or in long photoperiods, receive 8 hours of illumination in two fractions of 7 and 1-hour durations. The beginning of the 7-hour period is considered to be a subjective dawn, and the 1-hour light pulse is given at various times after dawn : at hours $11,14,17$ and 20.

The group receiving the light pulse during hour 17 after dawn has significantly higher prolactin levels than all the other groups. For example, in rams preconditioned in short photoperiods and after 5 weeks of light pulse treatment, the mean prolactin levels are $71 \pm 4 \mathrm{ng}$ (hour 11)) ; $68 \pm 5 \mathrm{ng}$ (hour 14) ; $225 \pm 22 \mathrm{ng}$ (hour 17) and $110 \pm 16 \mathrm{ng}$ (hour 20).

The prolactin level is higher during tha dark phase than during the light phase $(272 \pm$ $15 \mathrm{ng}$ vs $126+8 \mathrm{ng}$ in the group with light pulse at hour 17). This increase is essentially due to one important release resulting from the change in the light-dark sequence. Another release only occurs after the light pulse of one hour, if given at hour 17. However, these two prolactin releases are not sufficient to entirely explain this increase.

In domestic mammals, prolactin secretion can be influenced by different factors. In the male or the female, stress (Raud et al., 1971), estrogens (Schams and Reinhardt, 1973) and TRH (Debeljuk ef al., 1973) cause an increase in the level of plasma prolactin. Secretion of this hormone also depends on external factors such as ambient temperature and relative humidity (Tucker and Wetteman, 1976). However, one external factor-light-has been shown to be important in the ram (Pelletier, 1973) and in the bull (Bourne and Tucker, 1975), but has not received much attention in other species. This paper describes the effects of light on the secretion of prolactin in the sheep. 


\section{Seasonal variations in the level of plasma prolactin in the sheep. Photoperiodic effect}

Seasonal variations in plasma prolactin have been already described in cattle (Tucker et al., 1973 ; Schams and Reinhardt, 1974) and in goats (Buttle, 1974 ; Hart, 1975). One of us (Ravault, 1976) has shown such seasonal variations in the sheep. For that purpose, 9 lle-de-France lambs, born in autumn, were reared in pens under natural conditions of light and temperature. Blood samples $(5 \mathrm{ml})$ were collected weekly for two years, then every fifteen days during the third year. Blood collection was always carried out prior to feeding between 9 and $9.30 \mathrm{a} . \mathrm{m}$. The results of prolactin determination by radioimmunoassay $(\mathrm{Kann}, 1971)$ in the samples are shown in figure 1.

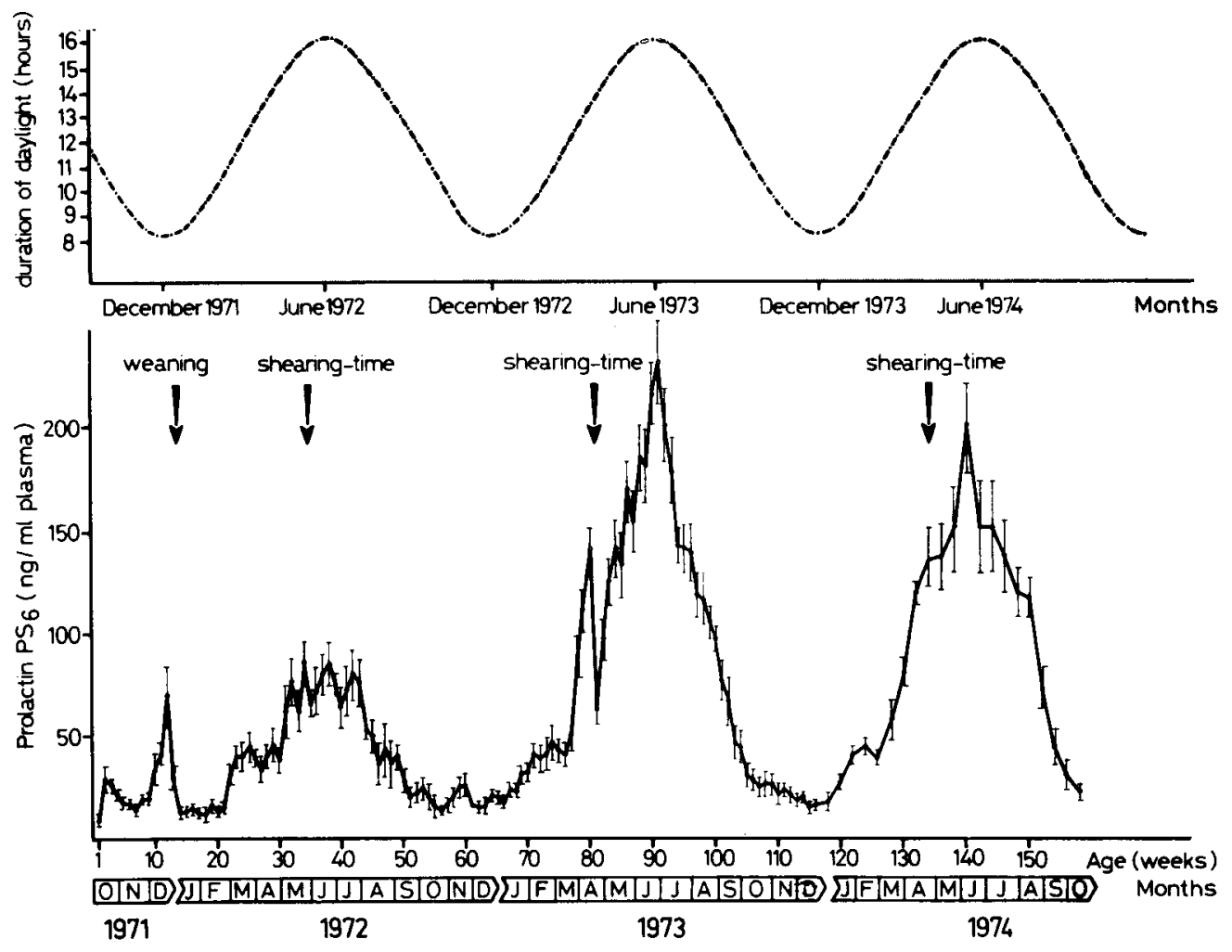

FIG. 1. - Seasonal variations of prolactin in the peripheral blood plasma of lle-de-France rams ( $=9 ; \mathrm{m} \pm \mathrm{SE}$ ) (from Ravault, 1976).

After a sharp increase about week 12, independent of the season (Ravault and Courot, 1975), the level of plasma prolactin fell rapidly to a basal level. From 15 weeks of age, variations in prolactin parallel variations in the daylength, showing a regular increase up to June, followed by a decline to a minimum in December. Similar variations were observed in the second and third years, but with an increased amplitude. 
These results indicate that prolactin secretion is maximum in summer (long days and high temperature) and minimum in winter (short days and low temperature).

However, it seems that the variations of temperature are not responsible for this pattern of prolactin secretion. Alberio and Ravault (unpublished communication) subjected other rams to either constant temperature (between $19^{\circ}$ and $21^{\circ} \mathrm{C}$ ) or to variable temperatures between $1^{\circ}$ and $24^{\circ} \mathrm{C}$, according to the season. The results (table 1) show that temperature did not significantly affect the level of prolactin.

\section{TABLE 1}

Mean level of plasma prolactin (ng PS6 $/ \mathrm{ml} \pm \mathrm{SE}$ ) in rams submitted to natural variations of temperature (minimum in December or 8 hours light, maximum in June or 16 hours light) or to constant temperafure $\left(20 \pm 1^{\circ} \mathrm{C}\right)$

\begin{tabular}{|c|c|c|c|}
\hline $\begin{array}{c}\text { Month } \\
\text { (duration of light) }\end{array}$ & \multicolumn{3}{|c|}{\begin{tabular}{cc}
\multicolumn{2}{c}{ Temperature } \\
not constant $\quad$ constant
\end{tabular}} \\
\hline $\begin{array}{l}\text { 1st year: } \\
\quad \text { - December }(8 \mathrm{~h} \mathrm{light)} \ldots \ldots \\
\text { — June }(16 \mathrm{~h} \text { light) } \ldots \ldots \ldots \ldots\end{array}$ & $\begin{array}{l}12 \pm 2 \\
90 \pm 8\end{array}$ & $\begin{aligned} 20 & \pm 9 \\
100 & \pm 10\end{aligned}$ & $\begin{array}{l}\text { NS* } \\
\text { NS * }\end{array}$ \\
\hline $\begin{array}{l}\text { 2nd year : } \\
\text { - December }(8 \mathrm{~h} \mathrm{light)..} \\
\text { - June }(16 \mathrm{~h} \text { light }) . . . .\end{array}$ & $\begin{aligned} 15 & \pm 3 \\
220 & \pm 20\end{aligned}$ & $\begin{aligned} 28 & \pm 4 \\
190 & \pm 22\end{aligned}$ & $\begin{array}{l}\text { NS * } \\
\text { NS * }\end{array}$ \\
\hline
\end{tabular}

On the other hand, daily daylength appears to influence the secretion of prolactin in entire or castrated adult rams (Pelletier, 1973). In this study, animals were subjected to a shortened annual photoperiodic cycle. The maximum and minimum periods of
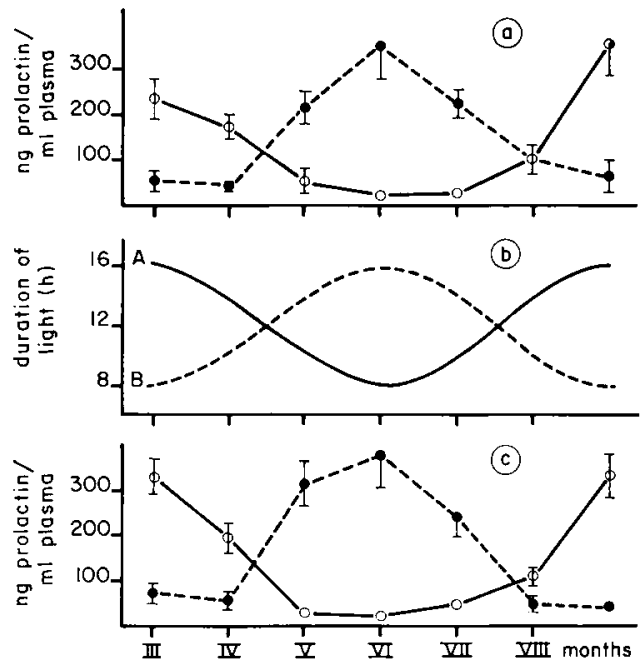

FIG. 2. - Experimental regimens (A and B) of "shorfened " onnual photoperiodic rhythm (b) and the mean plasma prolactin levels ( $\pm \mathrm{SE}$ ) of 2 groups of $\mathbf{8}$ entire (a) and 7 castrated (c) rams submitted to 2 opposite light regimens. Continuous line : animals under light regimen A; broken line : animals under light regimen B (from Pelletier, 1973). 
daily illumination were $16 \mathrm{~h}$ and $8 \mathrm{~h}$, respectively, and animals were subjected to two opposite patterns of gradually changing daylight hours between these extremes. A complete cycle took 6 months and temperature remained constant. The results (fig. 2) show the parallelism between variations in the light photoperiod and the plasma prolactin level in intact rams (correlotion coefficient $r=0.888 ; P<0.001$ ) and castrated animals $(r=0.887 ; P<0.001)$. Maximum prolactin values were found when animals were exposed to light for 16 hours. Such results have been confirmed by Forbes ef al. (1975). Thus, light appears to be a strong modulator of prolactin secretion. An increase in daily daylength stimulates this secretion, while a decrease is inhibitory. How does this light act?

\section{Attempt to determine a photoinducible phase for prolactin secretion during the diurnal rhythm}

How can the physiological system measure the daily variation of illumination? Different hypotheses have been given : the most explicit theories are those of Bunning (1960), Pittendrig and Minis (1964), Pittendrig (1966) and Pittendrig and Minis (1971). These authors have suggested that there is an endogenous daily rhythm in

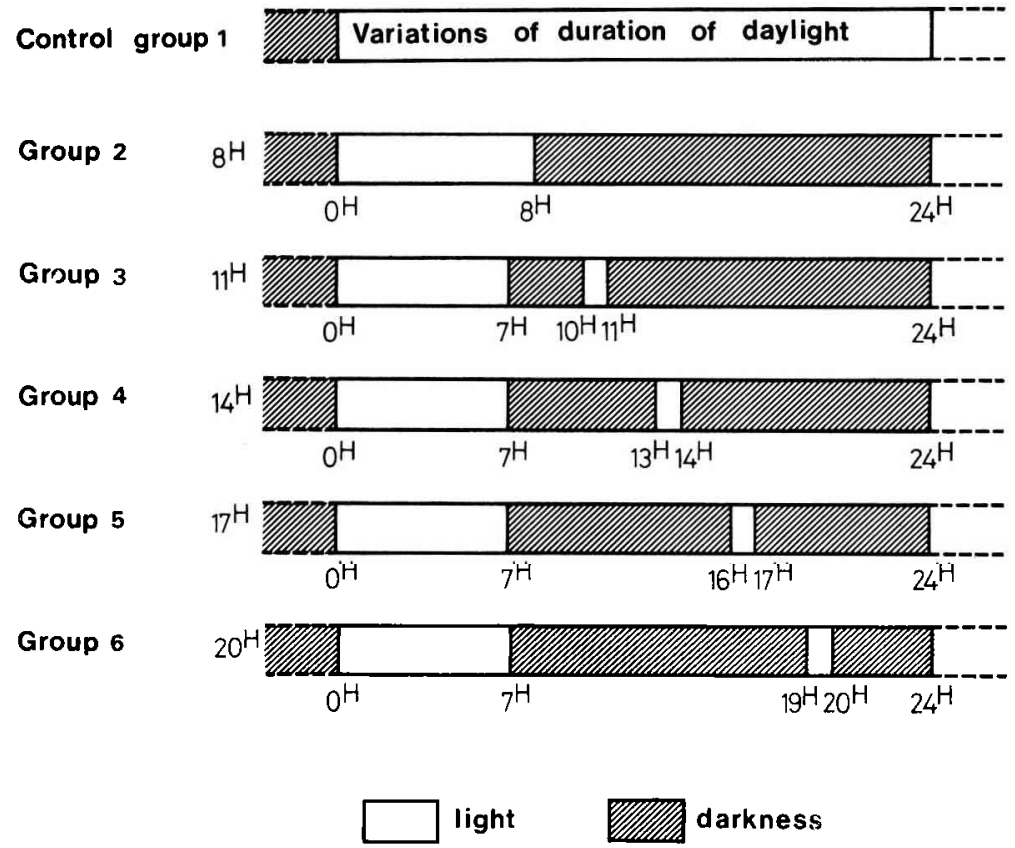

FIG. 3. - Protocol for the research of a photoinducible phase.

Position of the light pulses after the dawn.

Group 1 : control group, normal variations of duration of daylight.

Group 2 : 8 continuous hours.

Group $3: 11 \mathrm{~h}$, light pulse hour 11 after the dawn.

Group $4: 14 \mathrm{~h}$, light pulse hour 14 after the dawn.

Group $5: 17 \mathrm{~h}$, light pulse hour 17 after the dawn.

Group $6: 20 \mathrm{~h}$, light pulse hour 20 after the dawn. 
photosensitivity; this rhythm is imagined as having two halves per cycle : during one time the organism is light " insensitive », and during the other it becomes " sensitive» A physiological process is stimulated only if light coincides with the sensitive phase of the daily cycle. In winter, the photoperiods are too short to reach the sensitive phase but, as they lengthen in spring, light begins to progressively reach the phase, and so automatically to stimulate the physiological process. The existence of such a photoinducible phase, determined in relation to dawn, has been shown in birds (Hamner, 1963, 1964 ; Farner, 1965 ; Menaker, 1965 ; Follett and Sharp, 1969 ; Follett, 1973 ; Lofts and Lam, 1973). Could there not be a photoinducible phase for prolactin secretion in the sheep ? To determine this, we interrupted a 24-hour " night » cycle at different times with a short illumination (light pulse), a physiological response to the illumination thus indicating the presence of a sensitive phase.

Six lots of 5 adult Préalpes rams were used. Prior to the experiment they were all subjected to normal variations of daylength with an illumination of 300 lux at eye level. While a control group continued with a regime of normal daylight variation, the other five groups received 8 hours of illumination in two fractions, one of 7 and one of 1 hour duration. The beginning of the 7-hour period was considered to be a subjective dawn; the 1-hour light pulse was given at various times after dawn (fig. 3).

Prior to light pulse and approximately five weeks and 3 months after the beginning of the light treatment, plasma samples $(5 \mathrm{ml})$ were collected from the rams every hour for 25 hours. Collections in the dark were effected without added illumination. After cold centrifugation, the plasmas were stored at $-20^{\circ} \mathrm{C}$ until analyzed for prolactin titer by radioimmunoassay (Kann, 1971).

Two experiments were conducted : in the first, rams were preconditioned to short photoperiods (i.e. experiment begun January 1) and in the second, to long photoperiods (i.e. experiment begun June 8 ).

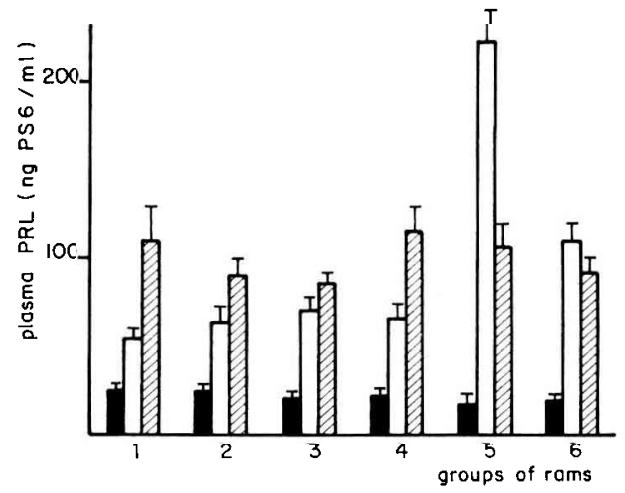

FIG، 4. - Daily mean of prolaclin level affer 5 weeks and 3 months of various light treatments in rams previously subjected to short photoperiods.

before treatment (daily daylength : $8 \mathrm{~h} 15 \mathrm{mn}$ ).

$\square$ weeks after the beginning of light treatment.

3 months after the beginning of light treatment.

1 : control group (daily daylength after 5 weeks treatment : $9 \mathrm{~h} 45 \mathrm{mn}$ and after 3 months : $13 \mathrm{~h} 15 \mathrm{mn}$ ). $2: 8$ hours continuous light per day.

$3,4,5,6: 7$ hours of light +1 hour of light pulse respectively hours $11,14,17$ and 20 after dawn. $T$ : standard error. 
A) Rams preconditioned to short photoperiods (fig. 4).

There were no significant differences in the mean prolactin levels for the 25 consecutive blood samples obtained before the light treatment commenced. The prolactin titer varied around $20 \pm 5 \mathrm{ng} / \mathrm{ml}$, a normal value under the light conditions used (8 h 15 mn light).

In contrast, after about 5 weeks of light pulse treatment, the mean prolactin level increased and significant differences were found between the treatment groups. In particular, group 5, receiving the light pulse during hour 17 after dawn, had significantly higher levels of prolactin than all other groups, including the one receiving a pulse hour 20 after dawn (group 6).

After 3 months of treatment, there was no significant difference between the groups. In the control group (1), the prolactin titer continued to augment with increased daylength. However, the prolactin level decreased in group 5 which received strong, high stimulation.

B) Rams preconditioned to long photoperiods (fig. 5).

As in the previous experiment, the mean prolactin levels, before light treatments began, were not significantly different between the groups. The mean value of $150 \pm 10 \mathrm{ng} / \mathrm{ml}$ is normal for animals in a $15 \mathrm{~h} 45 \mathrm{mn}$ illumination.

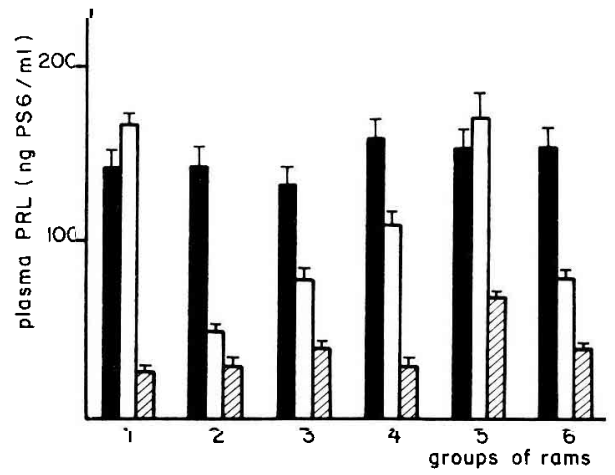

FIG. 5. - Daily mean of prolactin level after 4 weeks and 3 months of various light treatments in rams previously subjected to long photoperiods.

before treatment (daily daylength : 15 h $45 \mathrm{mn}$ ).

$\square 4$ weeks after the beginning of light treatment.

3 months after the beginning of light treatment.

1 : control group (daily daylength after 4 weeks treatment : $16 \mathrm{~h}$ and after 3 months : $12 \mathrm{~h} 15 \mathrm{mn}$ ). $2: 8$ hours continuous light per day.

$3,4,5,6: 7$ hours of light +1 hour of light pulse respectively hours $11,14,17$ and 20 after dawn. $T$ : standard error.

After 4 weeks of pulse treatments, the prolactin levels varied significantly between groups. During the treatment, the levels of prolactin did not increase significantly in the control group $(165 \pm 9 \mathrm{ng} / \mathrm{ml})$ and in group $5(168 \pm 12 \mathrm{ng} / \mathrm{ml})$. On the other hand, the prolactin levels decreased in all the groups, but most markedly in those which had the light pulse fartherest from hour 17 after dawn. 
After 3 months of pulse tratments, the prolactin levels fell in all groups and were not significantly different, except for group 5 (higher values). At this time, the control group received $12 \mathrm{~h} 45 \mathrm{mn}$ illumination per day.

C) Conclusions.

The results of these two experiments established that light pulses affect the secretion of prolactin in the ram. When the light pulse was given hour 17 after dawn, prolactin levels were maximal and comparable to those observed during long photoperiods $(16 \mathrm{~h})$, even though the total daily illumination was only 8 hours. With 8 continuous hours of light or with other pulse treatments, the prolactin levels were lower.

Thus, there seems to be a photoinducible phase for prolactin secretion during the diurnal rhythm. However, sensitivity is not constant, and there is evidence of "fatigue » effect.

The question remaining is : what is the pattern of prolactin secretion during diurnal rhythm in the ram?

\section{Comparison between prolactin levels during light and dark phases}

Several authors have established variations in prolactin secretion during the diurnal cycle with the maximum secretion of prolactin being observed at night. This effect has been shown in the male rat (Dunn et al., 1972 ; Ronnekleiv, Krulich and
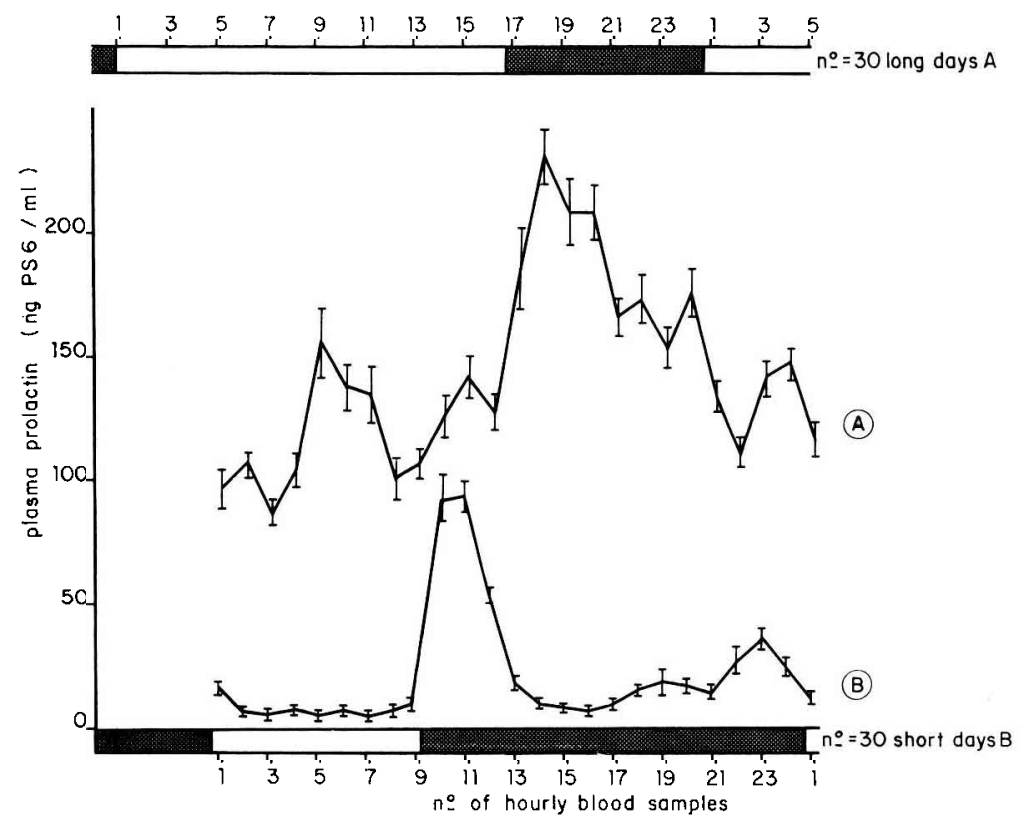

FIG. 6. - Hourly mean prolactin levels in rams preconditioned in short photoperiods (B) or in long photoperiods (A). ( $m$ : $\mathrm{SE}$ ).

$\square$ light ; darkness. 
MacCann, 1973 ; Simionescu, Sahleanu and Oprescu, 1974 ; Kizer et al., 1975), in the pregnant rat (Butcher, Fugo and Collins, 1972) or in the pseudopregnant rat (Freeman and Neill, 1972), in the ewe during the luteal phase (Davis and Borger, 1972), in the lactating cow (Koprowski, Tucker and Convey, 1970, 1972), in the rhesus monkey (Quadri and Spies, 1976) and in man (Sassin ef al., 1972 ; Vanhaelst ef al., 1973 ; Rubin et al., 1975). But some authors have determined either an inverse pattern in the rat (Hefco and Lackey, 1973), or no circadian rhythm in the ram (Chamley ef al., 1974) and in goat (Buttle, 1974).

We have studied the evolution of plasmatic prolactin level during the diurnal cycle in rams before the beginning of light pulse treatment, using either long photoperiods (June 8) or short photoperiods (December 15), and then on the same rams about five weeks after the beginning of the light pulse treatments.

In all groups, the mean prolactin level was higher in the dark than in the light phase. For example, in the pretreatment period (fig. 6), the mean prolactin level in 30 rams was $190 \pm 9 \mathrm{ng} / \mathrm{ml}$ (long photoperiods) and $32 \pm 4 \mathrm{ng} / \mathrm{ml}$ (short photoperiods) during the dark, compared with $112 \pm 5 \mathrm{ng} / \mathrm{ml}$ and $6 \pm 1 \mathrm{ng} / \mathrm{ml}$ during the light phases. The results after about one month of light treatment are shown in table 2.

TABLE 2

Mean prolactin level (ng PS6/ml $\pm \mathrm{SE}$ ) during the light and dark phase after about 5 weeks light pulse treatments

(groups 1, 2, 3, 4, 5, 6 : see protocol fig. 3)

\begin{tabular}{crrrr}
\hline & \multicolumn{4}{c}{ Rams preconditioned in } \\
\cline { 2 - 5 } Group & $\begin{array}{c}\text { short photoperiods } \\
\text { light phase }\end{array}$ & $\begin{array}{c}\text { long photoperiods } \\
\text { dark phase }\end{array}$ & light phase & dark phase \\
\hline & $36 \pm 3$ & $67 \pm 5^{*}$ & $147 \pm 6$ & $202 \pm 10^{*}$ \\
1 & $51 \pm 4$ & $70 \pm 7^{*}$ & $45 \pm 5$ & $50 \pm 4^{*}$ \\
2 & $37 \pm 2$ & $84 \pm 5^{*}$ & $51 \pm 3$ & $96 \pm 6^{*}$ \\
4 & $41 \pm 2$ & $79 \pm 4^{*}$ & $90 \pm 6$ & $114 \pm 6^{*}$ \\
5 & $126 \pm 8$ & $272 \pm 15^{*}$ & $107 \pm 7$ & $201 \pm 8^{*}$ \\
6 & $71 \pm 8$ & $125 \pm 8^{*}$ & $76 \pm 3$ & $79 \pm 2$ \\
& & & & \\
\hline
\end{tabular}

* significantly different from light phase.

This difference is due to the sharp increase in prolactin in the hour after the change from light to dark (fig. 7, 8). A high level is subsequently maintained for 2-3 hours, then falls gradually. The short duration of this peak explains why several authors have not found diurnal variations : blood sampling was not frequent enough.

Other low but significant peaks of prolactin were observed either at the end of the dark phase on rams preconditioned to short photoperiods, or during the light phase in rams preconditioned to long photoperiods (fig. 6). In the latter case, the peaks seem to have a 4-5 hour periodicity, but this may not be related to other phenomena, such as feeding (MacAtee and Trenkle, 1971). 
Generally, a one-hour light pulse in the dark phase decreases the prolactin level (table 3). The increase in prolactin during the three hours following the light pulse (table 4) is significant when the pulse occurs at hour 17 after dawn. In other cases, the increase is not significant; there is even a decrease when light pulse is situated at hour 11 or hour 20 after dawn.

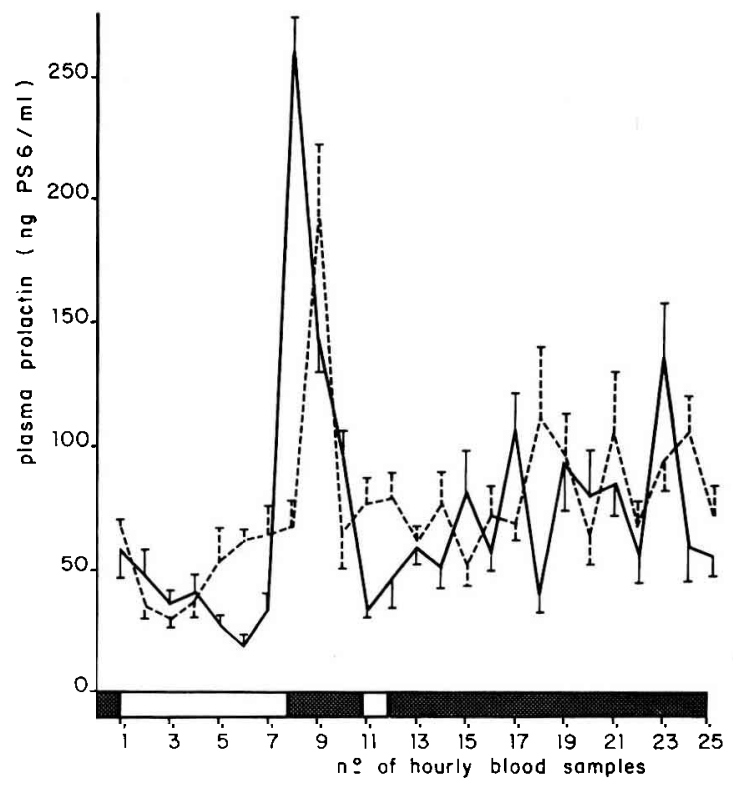

FIG. 7. - Hourly mean prolactin levels in rams preconditioned in short photoperiods ( $\rightarrow$ ) or in long photoperiods (- - ) subjected about 5 weeks, to a light pulse treatment at hour 11 after dawn (m \pm SE).

D light ; darkness.

These phenomena are particularly marked in rams preconditioned to short photoperiods. With rams preconditioned to long photoperiods, the phenomena are less marked, perhaps indicating the beginning of a fatigue effect on the photosensitive system controlling prolactin secretion.

Thus, the high prolactin levels associated with the pulse hour 17 after dawn, are essentially due to two important prolactin releases resulting from two changes in the light-dark sequence. This leads to a good coincidence with the periodic endogenous rhythm previously described, especially in the case of long photoperiods.

What is the mechanism of prolactin rhythm ? There are few experiments to provide data. In the rat, pinealectomy abolishes the diurnal rhythm in prolactin secretion (Ronnekleiv et al., 1973) as well as blocking the increase in prolactin observed in rats kept in continuous darkness (Relkin, 1972) and in blind, anosmic rats (Blask and Reiter, 1975). Thus, darkness may modify prolactin secretion by acting on the pineal gland, mediated by dopamine, serotonin or melatonin.

As hypothalamic dopamine inhibits prolactin secretion in the rat (Kamberi, Mical and Porter, 1971) or in the sheep (Davis and Borger, 1973), it seems that the 
period of darkness induces inactivation of the dopamine-stimulating system ; an injection of L. Dopa at about $00.30 \mathrm{~h}$ suppresses the noctural surges of prolactin in the rat (Hsueh and Voogt, 1975). However, there are few studies of diurnal variation in serum dopamine levels. Scheving ef al. (1968) have suggested a trimodal variation in dopamine secretion in the rat, and if this is also true for sheep, then the light pulse at hour 17 after dawn may modify the dopamine secretion.

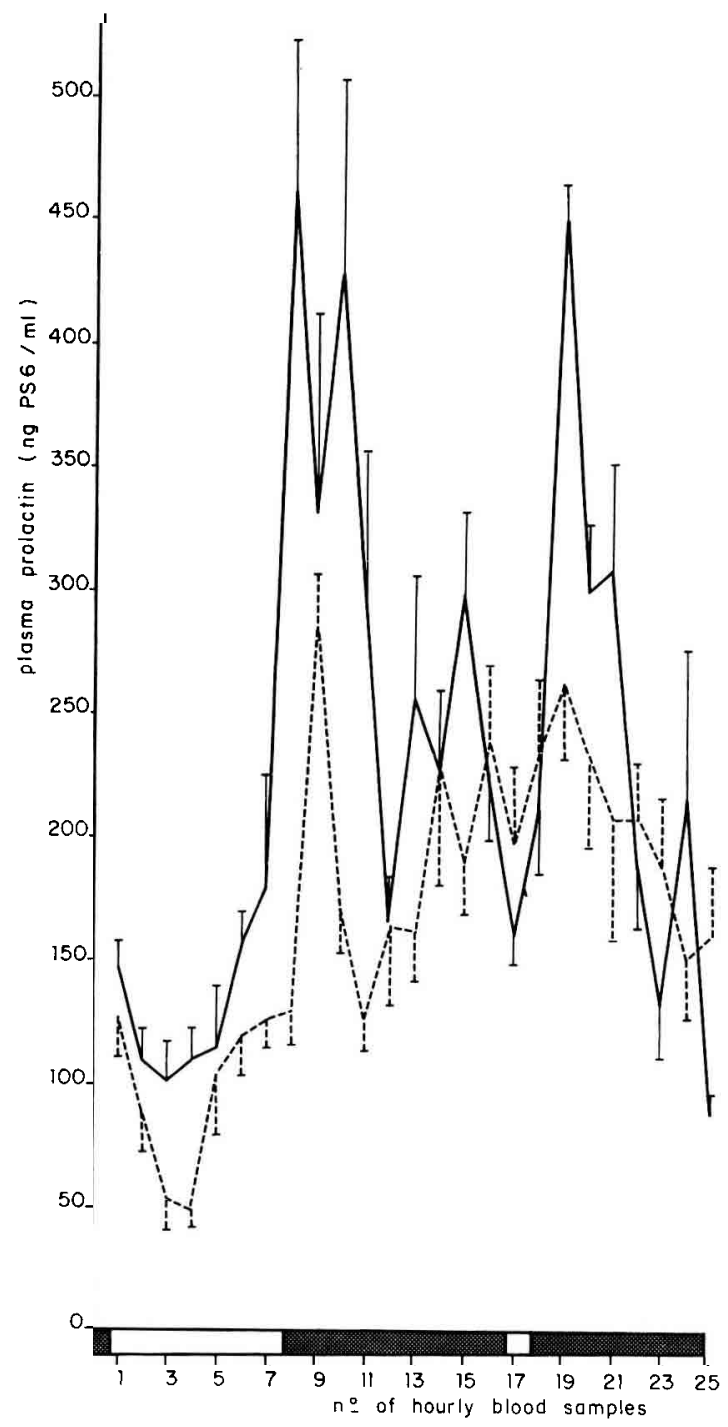

FIG. 8. - Hourly mean prolactin levels in rams preconditioned in short photoperiods (-) or in long photoperiods (- - -) subjected about 5 weeks, to a light pulse treatment at hour 17 after down $(m \pm$ SE).

口light ; darkness. 
It has also been shown that prolactin secretion is activated by serotonin-stimulating pathways (Lu and Meites, 1973 ; Kordon et al., 1974 ; Lawson and Gala, 1976). In the ferret conditioned to short days, Yates and Herbert (1976) found an increase in serotonin in the pineal gland and hypothalamus at the beginning of the dark phase. The serum serotonin of the rat increases at the beginning of the dark phase, but also at the end of the light phase (Scheving et al., 1972). In man, the highest values of serum serotonin are found during darkness (Sauerbier and Von Mayersbach, 1976), but Halberg ef al. (1967) observed the zenith of circadian rhythm for serotonin at the beginning of the day. In view of these results, it is difficult to conclude in favor of an hypothalamic effect of serotonin on the secretory rhythm of prolactin.

\section{TABLE 3}

Mean prolactin level (ng PS6/ml $\pm \mathrm{SE}$ ) in rams preconditioned in short photoperiods during the light pulse treatment and $1 \mathrm{~h}$ before and after, 5 weeks after the beginning of light pulse treatment

(groups 3, 4, 5, 6: see protocol fig. 3)

\begin{tabular}{cccc}
\hline Group & 1 h before light pulse & during light pulse & 1 h after light pulse \\
\hline 3 & $95 \pm 10$ & $33 \pm 3$ & $45 \pm 12$ \\
4 & $46 \pm 12$ & $36 \pm 7$ & $68 \pm 10$ \\
5 & $221 \pm 24$ & $160 \pm 8$ & $210 \pm 27$ \\
6 & $185 \pm 19$ & $123 \pm 14$ & $160 \pm 15$ \\
\hline
\end{tabular}

The injection of melatonin into the 3rd ventricle increases plasma prolactin levels in the rat (Kamberi, Mical and Porter, 1971) ; serum melatonin in this species is highest during the night (Pang and Ralph, 1975). Melatonin secretion has also been observed to increase at the beginning of darkness in ewes (Rollag and Niswender, 1976) and in man (Pelham et al., 1973). Despite the good correlation between melatonin and prolactin patterns, the relationship between the two needs further research.

TABLE 4

Mean prolactin level (ng PS6/ml $\pm \mathrm{SE}$ ) in rams preconditioned in short photoperiods $3 \mathrm{~h}$ before beginning and $3 \mathrm{~h}$ after the end of darkness, then $3 \mathrm{~h}$ before and after light pulse, 5 weeks after the beginning of light pulse treatment (group 3, 4, 5, 6 : see protocol fig. 3).

\begin{tabular}{ccccc}
\hline Group & $\begin{array}{c}3 \mathrm{~h} \text { before } \\
\text { beginning of darkness }\end{array}$ & $\begin{array}{c}3 \mathrm{~h} \text { after } \\
\text { the end of darkness }\end{array}$ & $\begin{array}{c}3 \mathrm{~h} \text { before } \\
\text { light pulse }\end{array}$ & $\begin{array}{c}3 \mathrm{~h} \text { after } \\
\text { light pulse }\end{array}$ \\
\hline 3 & $27 \pm 3$ & $166 \pm 19^{*}$ & $166 \pm 19$ & $52 \pm 5^{*}$ \\
4 & $44 \pm 6$ & $138 \pm 12^{*}$ & $54 \pm 6$ & $70 \pm 6$ \\
5 & $150 \pm 17$ & $407 \pm 44^{*}$ & $248 \pm 19$ & $320 \pm 29^{*}$ \\
6 & $82 \pm 10$ & $158 \pm 9^{*}$ & $167 \pm 11$ & $132 \pm 10$ \\
\hline
\end{tabular}

* Significantly different from $3 \mathrm{~h}$ before the beginning of darkness or light pulse. 
Nevertheless, it seems that light treatments affect both excretory and secretory pituitary activity. All the data on our light treatments support these concepts ; for example, the prolactin level observed in animals subjected to a light pulse at hour 17 after dawn is higher than that in all other treatments, even considering the period outside of the peak surges of prolactin due to the passage of darkness.

For this reason, we suggest that the ram has a photosensitive period for the secretion of prolactin.

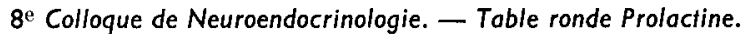
Tours, 7 septembre 1976.

Acknowledgments. - This work was supported by an ATP-CNRS No 1832 (Physiological Ecology). We thank Mr. B. Restall for the translation of the manuscript, Mr. Kann for supplying the iodinated prolactin and the NIH for the gift of ovine prolactin. We are also indebted to Agnès Daveau, Marie-Madeleine de Reviers, A. Caraty and the workers of the Unit of Physiology of Reproduction for taking blood samples during the diurnal rhythm.

Résumé. La sécrétion de prolactine subit d'importantes variations saisonnières chez les ovins. Ainsi, chez le mouton, les taux les plus élevés surviennent en été et les plus bas en hiver. Ces variations de sécrétion sont contrôlées par la lumière car un éclairement de durée identique à une longue photopériode entraîne un taux élevé de prolactine $(220 \pm 20 \mathrm{ng})$ et une courte photopériode de faibles taux (12 $\pm 2 \mathrm{ng})$.

En se basant sur l'hypothèse de Bunning, nous avons recherché une phase photosensible au cours du rythme diurne. Pour cela. des béliers préconditionnés en courte ou en longue photopériode recevaient $8 \mathrm{~h}$ d'éclairement en deux fractions d'une durée de $7 \mathrm{~h}$ et de $1 \mathrm{~h}$. Le début de la photopériode de $7 \mathrm{~h}$ était considéré comme une aube subjective et l'impulsion lumineuse était donnée à différents moments après l'aube, c'est-à-dire à la 11e, 14e, $17^{\mathrm{e}}$ ef $20^{\mathrm{e}}$ heure.

Le groupe qui recevait l'impulsion lumineuse à la 17 e heure après l'aube avait des taux significativement plus élevés que ceux des autres groupes. Chez des béliers préconditionnés en courte photopériode et après 5 semaines de traitements lumineux, les taux moyens de prolactine sont de $71 \pm 4 \mathrm{ng}$ (11e heure) ; $68 \pm 5 \mathrm{ng}$ (14e heure) ; $225 \pm 22 \mathrm{ng}$ (17e heure) et $110+16 \mathrm{ng}$ ( $20^{\mathrm{e}}$ heure).

Le taux de prolactine est plus haut pendant la phase obscure que pendant la phase claire $(272 \pm 15 \mathrm{ng}$ contre $126 \pm 8 \mathrm{ng}$ dans le groupe avec l'impulsion lumineuse à la $17 \mathrm{e}$ heure). Cette augmentation est due essentiellement à une importante décharge résultant du changement lumière-obscurité. Une telle décharge se produit après l'impulsion lumineuse de 1 heure si celle-ci est donnée à la $17 \mathrm{e}$ heure. Cependant, ces deux décharges de prolactine ne sont pas suffisantes pour expliquer cette augmentation. II semble exister une phase photosensible pour la sécrétion de prolactine.

\section{References}

BLASK D. E., REITER R. J., 1975. Pituitary and plasma L.H and prolactin levels in female rats rendered blind and anosmic : influence of the pineal gland. Biol. Reprod., 12, 329-334.

BOURNE R. A., TUCKER H. A., 1975. Serum prolactin and LH responses to photoperiod in bull calves. Endocrinology, 97, 473-475.

BUNNING E., 1960. Circadian rhythms and time-measurement in photoperiodism. In Biological cloks. Cold Spring Harb. Symp. Quant. Biol., 25, 249-257.

BUTCHER R. L., FUGO N. W., COLLINS W. E., 1972. Semicircadian rhythm in plasma levels of prolactin during early gestation in the rat. Endocrinology, 90, 1125-1127. 
BUTTLE H. L., 1974. Seasonal variation of prolactin in plasma of male goats. J. Reprod. Fert., 37, 95-99. CHAMLEY W. A., FELL L. R., ALFORD F. P., GODDING J. R., 1974. Twenty-four hour secrefory profiles of ovine prolactin and growth hormone. J. Endocr., 61, 165-169.

DAVIS S. L., BORGER M. L., 1972. Circadian prolactin release in cyclic ewes. J. Anim. Sci., 35, 239.

DAVIS S. L., BORGER M. L., 1973. Hypothalamic catecholamines effects on plasma levels of prolactin and growth hormone in sheep. Endocrinology, 92, 303-309.

DEBELJUK L., ARIMURA A. ,REDDING T., SCHALLY A. V., 1973. Effect of TRH and triiodothyronin on prolactin release in sheep. Proc. Soc. exp. Biol. Med., 142, 421-426.

DUNN J. D., ARIMURA A., SCHEVING L. E., 1972. Effect of stress on circadian periodicity in serum LH and prolactin concentration. Endocrinology, 90, 29-33.

FARNER D. S., 1965. Circadian systems in the photoperiodic responses of vertebrafes, 357-369. In ASCHOFF. J., Circadian clocks, North Holland Publ. Co., Amsterdam.

FOLLETT B. K., SHARP P. J., 1969. Circadian rhythmicity in photoperiodically induced gonadotropin release and gonadal growth in the quail. Nafure, 223, 968-971.

FOLLETT B. K., 1973. Circadian rhythms and photoperiodic time measurement in birds. J. Reprod. Fert., suppl. 19, 5-18.

FORBES J. M., DRIVER P. M., EL SHAHAT A. A., BOAZ T. G., SCANES C. G., 1975. The effect of daylength and level of feeding on serum prolactin in growing lambs. J. Endocr., 64, 549-554.

FREEMAN M. E., NEILL J. D., 1972. The pattern of prolactin secretion during pseudopregnancy in the rat : a daily nocturnal surge. Endocrinology, 90, 1292-1294.

HALBERG F., ANDERSON J. A., ERTEL R., BERENDES H., 1967. Circadian rhythm in serum 5 hydroxytryptamine of healthy men and male patients with mental retardation. Int. J. Neuropsychiatr., 3, 81-106.

HAMNER W. M., 1963. Diurnal rhythm and photoperiodism in festicular recrudescence of the House Finch. Science, 142, 1294-1295.

HAMNER W. M., 1964. Circadian control of photoperiodism in the House Finch demonstrated by interrupted - night experiments. Nalure, 203, 1400-1401.

HART I. C., 1975. Seasonal factors affecting the release of prolactin in goats in response to milking. J. Endocr., 64, 313-322.

HEFCO E., LACKEY R. L., 1973. Circadian variations of plasma levels of LH, FSH, prolactin and GH in normal male rats. Fed. Proc., 32, 375.

HSUEH S. C., VOOGT J. L., 1975. Effect of L-Dopa on nocturnal prolactin surges during pseudopregnancy. Biol. Reprod., 13, 223-227.

KAMBERI I. A., MICAL R. S., PORTER J. C., 1971. Effect of anterior pituitary perfusion and intraventricular injection of catecholamines on prolactin release. Endocrinology, 88, 1012-1020.

KANN G., 1971. Dosage radioimmunologique de la prolactine plasmatique chez les ovins. C. $R$. Acad. Sci., Poris, Sér. D, 272, 2808-2811.

KIZER J. S., ZIVIN J. A., JACOBOWITZ D. M., KOPLINI. J., 1975. The nyctohemeral rhythm of plasma prolactin : effects of ganglionectomy, pinealectomy, constant light, constant darkness or 6,0H-dopamine administration. Endocrinology, 96, 1230-1240.

KOPROWSKI J. A., TUCKER H. A., CONVEY E. M., 1970. Prolactin and growth hormone circadian periodicity. J. Anim. Sci., 31, 224-225.

KOPROWSKI J. A., TUCKER H. A., CONVEY E. M., 1972. Prolactin and growth hormone circadian periodicity in lactating cows. Proc. Soc. exp. Biol. Med., 140, 1012-1014.

KORDON C., BLAKE C. A., TERKEL J., SAWYER C. H., 1973-1974. Participation of serotonin-containing neurons in the suckling induced rise in plasma prolactin levels in lactating rats. Neuroendocrinology, 13, 213-223.

LAWSON D. M., GALA R. R., 1976. The interaction of dopaminergic and serotoninergic drugs on plasma prolactin in ovariectomized estrogen treated rats. Endocrinology, 98, 42-47.

LOFTS B., LAM W. L., 1973. Circadian regulation of gonadotrophin secretion. J. Reprod. Fert., suppl. 19, 19-34.

LU K., MEITES J., 1973. Effects of serotonin precursors and melatonin on serum prolactin release in rats. Endocrinology, 93, 152-155.

MacATEE J. W., TRENKLE A., 1971. Effects of feeding, fasting, glucose or arginine on plasma prolactin levels in the bovine. Endocrinology, 89, 730-734. 
MENAKER M., 1965. Circadian rhythms and photoperiodism, 385-395. In ASCHOFF J., Circadian clocks, North Holland Publ. Co., Amsterdam.

PANG S. F., RALPH C. L., 1975. Pineal and serum melatonin at midday and midnight following pinealectomy or castration in male rats. J. exp. Zool., 193, 275-280.

PELHAM R. W., VAUGHAN G. M., SANDOCK K. L., VAUGHAN M. K., 1973. Twenty four hour cycle of a melatonine-like substance in the plasma of human males. J. clin. Endocrinol. Metab., 37, 341-344.

PELLETIER J., 1973. Evidence for photoperiodic control of prolactin release in rams. J. Reprod. Ferf., 35, $143-147$.

PITTENDRIG C. S., MINIS D. H., 1964. The entrainment of circadian oscillations by light and their role as photoperiodic clocks. Amer. Natur., 98, 261-294.

PITTENDRIG C. S., 1966. The circadian oscillation in drosophila pseudo abscissa pupae - a model for the photoperiodic clock. Z. Pfphysiol., 54, 257-307.

PITTENDRIG C. S., MINIS D. H., 1971. The photoperiodic time measurement in Pectinophora - gossypiella and its relation to the circadian system in that species, 212-250. In MENAKER M., Biochronometry, Nat. Acad. Sci., Wash.

QUADRI S. K., SPIES H. G., 1976. Cyclic and diurnal patterns of serum prolactin in the rhesus monkey. Biol. Reprod., 14, 495-501.

RAUD H. R., KIDDY C. A., ODELL W. D., 1971. The effect of stress upon the determination of serum prolactin by radioimmunoassay. Proc. Soc. exp. Biol. Med., 136, 689-693.

RAVAULT J.-P., COUROT M., 1975. Blood prolactin in the male lamb from birth to puberty. J. Reprod. Fert., 42, 563-566.

RAVAULT J.-P., 1976. Prolactin in the ram : seasonal variations in the concentration of blood plasma from birth until three years old. Acta endocr., 83, 720-725.

RELKIN R., 1972. Rat pituitary and plasma prolactin levels after pinealectomy. J. Endocr., 53, 179-180.

ROLLAG M. D., NISWENDER G. D., 1976. Radioimmunoassay of serum concentrations of melatonin in sheep exposed to differentlighting regimens. Endocrinology, 98, 482-489.

RONNEKLEIV O. K., KRULICH L., MCCANN S. M., 1973. An early morning surge of prolactin in the male rat and its abolition by pinealectomy. Endocrinology, 92, 1339-1342.

RUBIN R. T., GOUIN P. R, LUBIN A., POLAND R. E., PIRKE K. M., 1975. Nocturnal increase of plasma testosterone in men : relation to gonadotropins and prolactin. J. clin. Endocrinol. Metab., 40, 1027-1033.

SASSIN J. F., FRANTZ A. G., WEITZMAN E. D., KAPEN S., 1972. Human prolactin : 24 hour pattern with increased release during sheep. Science, 177, 1205-1207.

SAUERBIER I., Von MAYERSBACH H., 1976. Circadian variations of serotonin levels in human blood. Horm. Metob. Res., 8, 157-158.

SCHAMS D., REINHARDT V., 1973. Immediate response of the plasma prolactin level to steroid hormone infusion in male and female cattle. Acfo endocr., suppl. 173, 38.

SCHAMS D., REINHARDT V., 1974. Influence of the season on plasma prolactin level in cattle from birth to maturity. Horm. Res., 5, 217-226.

SCHEVING L. E., HARRISON W. H., GORDON P., PAULY J. E., 1968. Daily fluctuation (circadian and ultradian) in biogenic amines of the rat brain. Amer. J. Physiol., 214, 166-173.

SCHEVING L. E., DUNN J. D., PAULY J. E., HARRISON W. H., 1972. Circadian variation in rat serum 5-hydroxytryptamine and effects of stimuli on the rhythm., Amer. J. Physiol., 222, 252-255.

SIMIONESCU L., SAHLEANU V., OPRESCU M., 1974. Circadian rhythm of serum and hypophysis prolactin in the male rat. Rev. roum. Med., 12, 347-354.

TUCKER H. A., KOPROWSKI J. A., BRITT J. H., OXENDER W. O., 1973. Serum prolactin and growth hormone in holstein bulls. J. Dairy Sci., 57, 1092-1094.

TUCKER H. A., WETTEMANN R. P., 1976. Effects of ambient temperature and relative humidity on serum prolactin and growth hormone in heifers. Proc. Soc. Biol. Med., 151, 623-628.

VANHAELST L., GOLSTEIN J., Van CAUTER E., L'HERMITE M., ROBYN C., 1973. Ełude simultanée des variations circadiennes des taux sanguins de TSH ef de prolactine hypophysaire chez l'homme. C. R. Acad. Sci., Poris, Sér. D, 276, 1875-1877.

YATES C. A., HERBERT J., 1976. Differential circadian rhythms in pineal and hypothalamic 5-HT induced by artificial photoperiods and melatonin. Nature, 262, 219-220. 